\title{
Does Institutional Ownership and Bank Monitoring Affect Agency Conflicts? Evidence from an Emerging Market
}

\author{
Bagus Dwi Ariyono ${ }^{1,}$ Bowo Setiyono ${ }^{2 *}$ \\ 1,2 Department of Management, Faculty of Economics and Business, Universitas Gadjah Mada, \\ Yogyakarta, 55281,Indonesia
}

\begin{tabular}{|c|c|}
\hline ABSTRACT & ARTICLE INFO \\
\hline $\begin{array}{l}\text { Introduction/Main Objectives: This study examines the effect of } \\
\text { institutional ownership, proxied by government and private } \\
\text { ownership, and bank monitoring on agency conflicts. Background } \\
\text { Problems: The previous literature focused on agency conflicts, } \\
\text { particularly those between managers and shareholders in developed } \\
\text { markets, with much less evidence being presented from emerging } \\
\text { ones. Novelty: We consider the role of creditors (the banks) in } \\
\text { mitigating agency conflicts, and the managers' irresponsible behavior, } \\
\text { which in previous studies has been largely under-elaborated. } \\
\text { Research Methods: Using } 1,525 \text { observations of } 305 \text { non-financial } \\
\text { companies that were listed in the } 2011-2015 \text { period, we employ the } \\
\text { generalized least squares method to deal with potential econometric } \\
\text { concern such as autocorrelation and heteroscedasticity. } \\
\text { Finding/Results: We find that institutional ownership and bank } \\
\text { monitoring, proxied by the number of banks and the share of their } \\
\text { loans, are negatively related to agency conflicts. Conclusion: Banks } \\
\text { and institutional ownership lead to lower agency conflicts. However, } \\
\text { one should mitigate free-rider problems emanated from these } \\
\text { relationships. }\end{array}$ & $\begin{array}{l}\text { Article information: } \\
\text { Received in } 1 \text { March } \\
2020 . \\
\text { Received in revised form } \\
27 \text { May } 2020 . \\
\text { Received in revised form } \\
23 \text { June } 2020 . \\
\text { Accepted } 30 \text { June2020 } \\
\text { Keywords: } \\
\text { agency conflict, } \\
\text { institutional ownership, } \\
\text { government ownership, } \\
\text { bank monitoring }\end{array}$ \\
\hline
\end{tabular}

\footnotetext{
* Corresponding Author at Department of Management, Faculty of Economics and Business, Universitas Gadjah Mada, Jalan Sosio Humaniora No. 1, Yogyakarta 55281, Indonesia. E-mail address: bagus.dwi.a@mail.ugm.ac.id (author\#1), bowo@ugm.ac.id (author\#2)
} 


\section{INTRODUCTION}

The literature contends that a firm is a set of various contracts among related parties in which they often have different and conflicting interests among each other, which are the socalled agency conflicts (Jensen \&Meckling, 1976). Studies suggest that various measures have been employed to mitigate such issues, particularly the design of the ownership's structure (Jensen \&Meckling, 1976; Ang et al., 2000; Singh \& Davidson, 2003; Fleming et al., 2005; Florackis, 2008).

In emerging markets (EM), such agency conflicts are more complex given their weak institutional development and investor protection(Claessens\&Yurtoglu,2013). Ownership structure become a pivotal factor in shaping firm governance and performance, and hence most firms in Southeast Asia have concentrated ownerships (Claessens et al., 2002; La Porta, Lopez-de-Silanes\&Shleifer, 1999). In Indonesia, for example, institutional investors make up more than $90 \%$ of ownerships (OJK, 2017). On the one hand, the large and sophisticated institutional investors presumably encourage better corporate governance; thus reducing agency conflict (Shleifer\&Vishny, 1986; Demsetz, 1983 in Agrawal \&Mandelker, 1990; Bathala et al., 1994; Ang et al., 2000; Gillan\& Starks, 2000; Noe, 2002). On the other hand, they are prone to push a firm's managers to act in the best interests of these investors, causing a conflict of interest between the majority and minority shareholders (agency problem type II). Institutional ownership, as the majority shareholder, may take opportunistic behavior at the expense of the other shareholders (Shleifer\&Vishny, 1997; La Porta et al., 1999; Claessens et al., 2000; Muniandy et al., 2016).

We argue that to obtain the funding needed for their investments, firms in emerging markets, including Indonesia, rely on bank loans rather than on the capital markets, consdering their level of developments (see, e.g., survey by Demirgüç-Kunt\& Levine, 1999; Beck et al., 2010). This implies the firms' high dependence on loans as their source of funds, rendering the banks' monitoring roles as being to enforce the loan agreements, to discipline the firm's managers, and to eventually reduce the agency conflict between the different parties in the firm (e.g. between manager and shareholders).The inclusion of banks in the relationship between the firm's managers and shareholders would serve as the external mechanism of good corporate governance, by which agency conflicts in the firm could be mitigated. In order to achieve these objectives, banks would require the firms to provide the necessary disclosure, from which they can assess the risk or urge certain actions be taken by the firms' managers, thus improving firm performance (Gillan\& Starks, 2000; Fama, 1985 in Florackis, 2008; Ahn\& Choi, 2009; Fok et al., 2004; Byers et al., 2008; Dass\& Massa, 2011, Setiyono, B., \& Tarazi, A. 2014).

A bank lessens its monitoring of its borrowers when another bank also lends money to the same borrower, a situation which probably discourages bank from closely monitoring its debtor due to the assumption that the other creditor bank is monitoring the firm, leading to a free-riding problem (Ang et al., 2000; Florackis et al., 2008). However, a higher loan proportion from a bank entails tougher bank monitoring of the firm because of the higher credit risk exposure, which increases with the size of the corporate loan (Ang et al., 2000).Considering that the weak investor protection might exaggerate conflicts among shareholders, creditors/lenders and managers, the presence of a number of banks arguably would mitigate the potential conflicts between the parties, yet at the same time might induce free-riding by them. 
Our study contributes to the existing literature by showing evidence of the impact of institutional ownership on firms' agency conflicts by considering different levels of their banks' monitoring, which has been understudied in the previous literature (see, e.g., Ang et al., 2000; Lin \& Fu, 2017) as it only focused on the institutional ownership-agency conflict relationship. Also, Dass and Massa (2011) only tested the impact of the lending bank on firm governance. We also contribute to the existing literature by providing complementary evidence about the effect of external governance mechanisms and certain types of ownership on the agency conflict, in addition to the current studies in the Asian context, for instance, those by Wiwattanakantang(2001) and Lin \& Lin (2013)that focused on performance.

We, hence, advance the question of whether institutional ownership and bank monitoring mitigate agency conflicts, and do they eventually affect firm performance? This study broadens the factors affecting agency conflict by assessing bank monitoring, proxies by the number of banks and the bank loan ratio, in addition to ownership structure, which was more frequently tested in the previous studies.

Whilst other studies provide evidence from developed countries (e.g., McKnight \& Weir, 2009; Agrawal \&Knoeber, 1996; Ang et al., 2000), we extend these study to a less elaborated-on area, an emerging market, which is notably different in the nature of its investor protection, governance mechanism and ownership structure compared to their counterparts in the Western or developed countries (Claessens \&Yurtoglu, 2013).

Using 1,525 observations of non-financial companies that were already listed during the period from 2011 to2015, this study aims to test the effect of institutional ownerships and bank monitoring on agency conflicts. The ratios of asset utilization, and sale sand general and administrative expenses are used as measures of the agency conflict. This study also examines the effect of institutional ownership on agency conflicts at different levels of bank monitoring measured by the number of banks and their loan shares. There might be free-riders among the parties overseeing the firms, based on the fact that several lending banks may concurrently monitor them, resulting in unclear ultimate effects. Our evidence suggests that the influence of institutional ownership on agency conflict varies with different levels of bank monitoring, supporting Yu et al. (2012) and Shepherd et al. (2007).

This paper is organized as follows: It begins with a review of related literature on the agency theory, ownerships, and monitoring by banks. Further, the subsequent sections of this paper will discuss the methodological approach used, the empirical results, and conclusions.

\section{LITERATURE REVIEW}

\section{Agency Conflict and Ownership}

Agency relationships have been a pivotal dimension since the seminal work of Jensen and Meckling (1976). They contended that in a contract between the principals (i.e., shareholders) that delegates the agent (i.e. the management) to serve their interests, conflicts potentially emerge because the managers are inclined to serve their own interests and take opportunistic behavior. In firms with highly concentrated ownership, however, agency conflicts may also occur among their shareholders, particularly between the majority and minority ones (see, e.g., Ang et al., 2000; Singh \& Davidson, 2003; Fleming et al., 2005; Florackis, 2008).

The active monitoring hypothesis argues that institutional investors will use their advantages 
to actively monitor the management (Demsetz, 1983; Shleifer\&Vishny, 1986 in Agrawal \&Mandelker, 1990). One of the advantages is the considerably large amount of invested capital and the skills that institutional investors possess, meaning they should be better at supervising the management and realizing substantial returns vis-á-vis the small investors. The large ownership, and hence its returns, should be more than enough to compensate for the monitoring costs incurred by the institutions (Shleifer\&Vishny, 1986; Bathala et al., 1994; Gillan\& Starks, 2000; Chung \& Lee, 2020). Further, some note that institutional investors have a superior capability, professional knowledge, and voting interests to encourage managers to improve efficiency and governance, and to help them make better decisions (David \&Kochhar, 1996; Lin \& Fu, 2017).

Agrawal (1990) described the passive voting hypothesis, stating that institutional investors tend to follow management decisions, abstain in voting, or choose to sell their shares to avoid having to vote. According to this view, institutional ownerships will have no effect on a firm. Accordingly, David and Kochhar (1996) argued that there are some obstacles that hinder the institutional ownerships' significantly impact on firm performance, particularly due to the investors' institutional business relationships with the firm and the regulatory limit.

In contrast, the exploitation hypothesis posits that large investors collude with managers to exploit minority shareholders, rendering any management misbehavior done for the managers' benefit also beneficial for them. Shleifer and Vishny (1997) argued that large investors such as institutional owners might destroy the value of the firm due to the conflict of interests with other investors. The majority shareholders may prioritize themselves by sabotaging other shareholders, requiring special dividends for themselves, or exploiting business opportunities with associated companies.

Various studies have put much effort into examining agency conflicts with regard to institutional ownership, and find inconsistent results such as in the UK (e.g. McKnight and Weir, 2009), in the U.S (e.g., Agrawal and Knoeber,1996; Ang et al., 2000), and Asia (e.g., Lin \& Fu, 2017). Another strand of the literature elaborates on the role of government ownership of firms. On one hand, governments are regarded as lacking the supervisory incentives and skills, because they are under pressure to serve certain political interests (Qi et al., 2008), and to achieve political objectives, possibly at the expense of the firm itself and the general public (Shleifer \&Vishny, 1994 in La Porta, 1999). On the other hand, these studies also document the government's role in advancing economic growth, including through their control over firms (e.g., Ang and Ding, 2006; Ahmad et al., 2008).

\section{Debt, Bank Loan, and Agency Conflict}

In addition to the ownership structure, debt might be regarded as a mechanism to mitigate the agency conflict in a firm. Jensen (1986) argued that debt contains a commitment to pay a part of the free cash flow in the future, and hence it plays a role in reducing the cash available to the managers, which otherwise could be used to pay for perks or other managers' private facilities. The debt contract should encourage managers to increase their firm's efficiency. Debt obtained from banks (loans) is regarded differently, compared to that from other funds providers, because banks are presumably better at accessing and utilizing information about firms. Each bank has not only dealt with one or two debtor firms in the past, but also with many other firms from various industries. From that, a bank is able to extrapolate information in order 
to assess the performance and prospects of potential borrowers (Boot, 2000). Furthermore, the obligation for the firm to share its operational information with the lending bank encourages the firm to improve its governance (Fama, 1985; Dass\& Massa, 2011), to ensure all the loans are repaid by the firm in accordance with the contract and to keep the bank's credit risk low (Diamond, 1984; Freixas\&Rochet, 2008).

In bank-firm relationships, a firm might decide to borrow either from only one or several banks simultaneously. In the case of borrowing from several banks (multiple banking), Diamond (1984) argued that incentives to monitor the firm by Bank A, for instance, will diminish if there is a greater presence of other banks (Bank B, Bank $\mathrm{C}$ etc.), triggering a free-rider problem where each bank will loosen its monitoring on the firm in the hope that the others will maintain or increase their levels. The bank probably expects the duration of its relationship with the firm to be short, given the possibility of the firm switching to another bank. However, since the investor protection and institutional development levels in emerging countries are largely weak (see, e.g., Claessens et al, 2000; Claessens and Yurtoglu, 2013), the incentive for continued monitoring by each bank in such an arrangement is intensified. For the arguments above, the net effect of multiple banking on the firm, particularly in emerging markets, remains debatable.

With regards to the borrowing relationship, previous studies documented that borrowing from several banks is related to higher free-rider problems (Yu et al., 2012), agency conflict (Ang et al., 2000) and lower performance (Fok et al., 2004). In case the firm only borrows from one bank, this bank will solely bear the credit risk, as opposed to borrowing from multiple banks. Other studies, however, suggest that as a firm increases its borrowing from the bank, the credit risk will go up, which in turn pushes the bank to stricken the loan monitoring (Khalil \&Parigi, 1998 in Dass\&Masa, 2009; Ahn\& Choi, 2009; Fok et al., 2004). Several studies conclude that bank loans, measured by the total bank loan divided by the total assets of the firm, relate to less agency conflict (Ang et al., 2000), lower earnings management behavior (Ahn and Choi, 2009), lower over/underinvestment problems (Setiawan, 2012), and surprisingly to lower performance (Fok et al., 2004).

\section{DATA AND METHOD}

This study used a sample of firms listed on the Indonesian Stock Exchange (IDX) between2011 and2015. Firms from the financial sectors were not included in the study due to differences in the regulations governing them, and their characteristics. Data on the firms were collected from various sources including the IDX official website, the firms' websites, and the Bloomberg and OSIRIS databases. The sample consisted of 305 firms with the data taken throughout 5 periods, resulting in 1,525 observations. As autocorrelation and heteroscedasticity are presumably observable in all the equations, we deployed the generalized least squares method to deal with such concerns.

\section{Variables Measurement}

\subsection{Dependent Variable}

The dependent variable in this study was agency conflict (CONFLICT). Previous studies (e.g., Ang et al., 2000; Singh \& Davidson, 2003; Fleming et al., 2005) used two proxies to represent the agency conflict variable used in this study: 1) the asset utilization ratio (AUR) and, 2) the sales, general and administrative (ADM) expense ratio.

The AUR is calculated by dividing sales by total assets, as adopted by Ang et al. (2000), Singh and Davidson (2003), and Fleming et al. 
(2005). A low ratio will arise from improper investment decisions, failure to use the assets productively and an excessive consumption of perks (Ang et al., 2000; Singh \& Davidson, 2003; Fleming et al., 2005). Meanwhile a high ratio reflects the management's efficiency in managing the assets and creating value for the firm's owners. Greater agency conflict is reflected by a lower asset utilization ratio.

The second measure used is the sales, general and administrative (ADM) expense ratio, calculated as sales, general and administrative expenses divided by annual sales. The numerator includes management salaries, insurance, supplies, travel expenses, and other discretionary expenses. This P\&L's item is considered to be a proxy of agency conflict, because it describes the extent of the expenses, particularly excessive perquisites (e.g., a high expense ratio indicates high agency conflict).

\subsection{Independent Variables}

a) Institutional ownership (Inst)

We use institutional ownership as our main variable which is measured by dividing the numbers of outstanding shares held by the institutions by the total number of the firms' outstanding shares, as in Lin \&Fu (2017), Chen (2001), Chen, Harford, \&Li (2007), and Ferreira \&Matos (2008). For further checking, we split this variable into government ownership (GOV), and private institutional ownership (PRIV). Hence, we set the total institutional ownership as the sum of both types of ownership.

\section{b) Bank Monitoring (MON)}

The bank monitoring used in this study was measured using two proxies for the firm level: the number of banks (NUM) and the ratio of the bank loans(LOANRATIO). We used the number of banks as the bank monitoring proxy, as in Ang et al. (2000), Fok et al. (2004), Ahn and Choi (2009), and $\mathrm{Yu}$ et al. (2012). The number of banks variable was then expressed as the natural logarithm of the number of banks plus one.

The ratio of bank loans was calculated by dividing the amount of bank loans by the firm's total assets, as per Ahn and Choi (2009) and Setiawan (2012).

c) Dummy Bank Monitoring (dMON)

The bank monitoring dummy variable was used as a moderation variable. There are two bank monitoring dummy variable sin this research: the dummy number of banks (dNUM) and the dummy ratio of bank loans (dLOANRATIO)at the firm level. The variable dNUM was used to distinguish the firms with loans from a large number of banks from firms with loans from only one or a few banks. A firm has a high bank number when it receives loans from more banks than the median value of the NUM variable. Dummy 1 is given to firms with a higher-than-median bank number and 0 otherwise; while dLOANRATIO sets 1 for firms with high bank loan ratios, which are those where the bank loan ratio is higher than the median value of the loan ratio variable, and 0 otherwise.

\subsection{Control Variables}

Singh and Davidson (2003) argued the effect of size on the costs incurred by firms. Ang et al. (2000) also controlled for the size of firms because of significant cost differences among different sized firms. Doukaset al. (2000), in McKnight and Weir (2009), contended that the increased agency conflict in bigger firms was due to the complexity of the management and the information supplied by them. Firm size (SIZE)was estimated to affect the agency 
conflict and was measured by the firm's total assets.

Firms that have been operating for some time are considered to have a well-structured operation and sufficient resources (Ariff et al., 2007). In addition, the firms will take their reputation hence we expect there is a negative relationship between the age of the firm (AGE) and agency conflict.

We control for industry (IND) because each industrial sector has different interests related to inventories and fixed assets, which impacts on the efficiency difference between industries (Ang et al., 2000). The year of observation was also included as a control variable. This was to anticipate circumstance differences in different years that affect the asset utilization ratio as well as the sales, general and administrative expense ratio.

\section{Empirical Model}

To examine the effect of institutional ownerships and bank supervision on agency conflict, we specify our model as follows:

$$
\begin{gathered}
\text { CONFLICT }=\alpha+\beta_{1} \text { INST }_{i t}+\beta_{2} \text { MON }_{\text {it }}+ \\
\beta_{3} \text { SIZE }_{i t}+\beta_{4} \text { AGE }_{i t}+\beta_{5} \text { IND }+ \\
\beta_{6} \text { YEAR }+\varepsilon
\end{gathered}
$$

CONFLICT is the agency conflict proxied by the asset utilization ratio (AUR) and the sales, general and administrative (ADM) expense ratio. INST shows the portion of institutional ownership that includes total institutional ownership (INST), and government (GOV) and private (PRIV) ownership. MON is bank monitoring proxied by the bank lender number (NUM) and total bank loans to total assets ratio (LOANRATIO). SIZE is the firm's size measured by its total assets, AGE shows the firms' age measured from the difference between the year of observation and the year the firm was incorporated. IND and YEAR are dummies for the industrial sector and year.

Accordingly, to examine the effect of institutional ownership on agency conflict at different levels of bank monitoring, we set our model as follows:

$$
\begin{gathered}
\text { CONFLICT }=\alpha+\beta_{1} \mathrm{INST}_{i t}+\beta_{2} \mathrm{dMON}_{\text {it }}+ \\
\beta_{3} \mathrm{INST}^{2} \mathrm{dMON}_{\mathrm{it}}+\beta_{4} \mathrm{SIZE}_{\mathrm{i}, \mathrm{t}}+ \\
\beta_{5} \mathrm{AGE}_{\mathrm{it}}+\beta_{6} \mathrm{IND}+\beta_{7} \mathrm{YEAR}+\varepsilon
\end{gathered}
$$

CONFLICT is the agency conflict proxied by the asset utilization ratio (AUR) and the sales, general and administrative (ADM) expense ratio. INST shows the portion of institutional ownership, including total institutional ownership (INST), and government (GOV) and private institutions (PRIV) ownership. dMON is a dummy describing different levels of bank monitoring, consisted of dNUM(dummy number of bank lenders) and dLOANRATIO(dummy total bank loans ratio to total assets). The sample will have a dNUM value of 1 if it borrows from a bank number higher than the median and 0 otherwise. The sample will have a dLOANRATIO value of 1 if its bank debt ratio is higher than the median and 0 otherwise. Also variable INST $* \mathbf{d M O N}$ is an interaction variable between INST ownership and dMON.

\section{RESULTS AND DISCUSSION}

\section{Descriptive statistics}

In this section, we report the descriptive statistics of the variables in this research. 
Table 1. Descriptive statistics

\begin{tabular}{ccccccccc}
\hline VAR. & $\mathbf{N}$ & Mean & Med & Min & Max & SD & Skew. & Kurt. \\
\hline AUR & 1,525 & 0.953 & 0.804 & 0.0144 & 3.788 & 0.738 & 1.450 & 5.458 \\
ADM & 1,277 & 0.115 & 0.064 & 0.0063 & 1.034 & 0.154 & 3.517 & 18.200 \\
INST & 1,525 & 0.675 & 0.700 & 0 & 0.999 & 0.213 & -0.894 & 3.805 \\
GOV & 1,525 & 0.0410 & 0 & 0 & 0.800 & 0.160 & 3.784 & 15.78 \\
PRIV & 1,525 & 0.633 & 0.675 & 0 & 0.999 & 0.260 & -0.941 & 3.283 \\
Num & 1,489 & 4.059 & 3 & 0 & 21 & 4.040 & 2.003 & 7.581 \\
LOANRATIO & 1,489 & 0.187 & 0.159 & 0 & 0.762 & 0.163 & 1.108 & 4.228 \\
Size (million) & 1,525 & $7,737,152$ & $2,089,516$ & $3,092.97$ & $2.45 \mathrm{e}+08$ & $1.83 \mathrm{e}+07$ & 6.643 & 64.420 \\
Age (year) & 1,525 & 29.721 & 28 & 2 & 114 & 17.233 & 1.718 & 8.498 \\
\hline
\end{tabular}

Source: Author calculations

Before we proceeded further, we excluded the largest and smallest $1 \%$ extreme values in this study to mitigate the outlier problem. We finally observed the average of AUR is 0.953 and ADM is 0.015 . The INST variable had an average of 0.675 , indicating firm ownership in Indonesia tends to be concentrated. The GOV variable showed the government's average ownership of shares in firms is 0.04. The ownership of shares by the government is low, and only about $10 \%$ of firms have some government ownership. The PRIV variable showed the percentage of shares owned by private institutions is approximately 0.633 .

The NUM variable showed the number of banks that lento a particular firm (approximately four banks). This data supports Yu et al. (2012), who stated that firms in developing countries generally obtain loans from more than one bank. While the other proxy for the bank monitoring, LOANRATIO, showed mean of 0.187 with the highest debt ratio reaching 0.762 . The total assets in this study had an average value of Rp7.73trillionRp2.1 trillion. Observation of the firm's age finds that the firms in this study are 29.72 years old, on average, with a median of 28 years old. All the variables indicated an adequate heterogeneity that allowed us to continue onto the next analysis.

\section{Univariate Analysis}

Table 2 shows the result of the univariate analysis on the samples grouped by the magnitude (high vs. low) of each type of agency conflict variable. The subsample with a higher AUR (lower ADM) than the median AUR (ADM) is classified as a low agency conflict, whereas the subsamples with a lower AUR (higher ADM) than the median AUR (ADM) are high agency conflicts. Based on AUR, firms with low agency conflicts have a higher average percentage of total institutional ownership and private institutions, a smaller size, and older age. AUR as a proxy of agency conflict does not show any significant difference in the bank monitoring variable, including the bank number and bank debt ratio.

Whereas based on ADM, the subsample with a low agency conflict has a higher total of institutional ownership and private ownership, a higher number of bank lenders, a higher bank debt ratio, bigger size, and older age. The univariate test result fails to find any differences in government institutional ownership; either for the agency conflict measurement based on AUR or ADM. The SIZE control variable also shows inconsistent results in both the agency conflict's proxies. 


\section{Multivariate Analysis}

In this section the regressions of agency conflict measures (AUR, ADM) on the institutional ownership (INST, GOV, PRIV) and bank monitoring (NUM, LONRATIO) are discussed.

\subsection{Agency Conflict as Measured by Asset Utilization Ratio}

Table 3 shows the regression result using AUR as an agency conflict proxy. This research regressed each of the institutional ownership variables with the bank number and bank loan ratio as bank monitoring proxies. The control variables used consisted of size, age, sector, and year of observation, but only the size and age variables are shown in the table.

Table 2. Univariate analysis results

\begin{tabular}{ccccccccc}
\hline \multicolumn{9}{c}{ AUR } \\
\hline Variable & High & Low & Diff & p-value & High & Low & Diff & $\boldsymbol{p}$-value \\
INST & 0.712 & 0.638 & 0.074 & $0.0000^{* * *}$ & 0.666 & 0.696 & -0.030 & $0.0089^{* * *}$ \\
GOV & 0.043 & 0.038 & 0.005 & 0.4708 & 0.050 & 0.044 & 0.006 & 0.5927 \\
PRIV & 0.667 & 0.599 & 0.068 & $0.0000^{* * *}$ & 0.616 & 0.650 & -0.034 & $0.0214^{* *}$ \\
NUM & 3.841 & 4.181 & -0.340 & 0.1019 & 3.478 & 4.516 & -1.038 & $0.0000^{* * *}$ \\
LOANRATIO & 0.190 & 0.195 & -0.005 & 0.6472 & 0.170 & 0.204 & -0.034 & $0.0002^{* * *}$ \\
SIZE & $5,704,760$ & $9,769,543$ & $-4,064,783$ & $0.0000^{* * *}$ & $4,982,241$ & $1.09 \mathrm{e}+07$ & $-5,945,363$ & $0.0000^{* * *}$ \\
AGE & 32.807 & 26.635 & 6.172 & $0.0000^{* * *}$ & 28.387 & 32.362 & -3.975 & $0.0000^{* * *}$ \\
\hline
\end{tabular}

Note: This table reports t-test results for INST, GOV, PRIV, num, loan ratio, size and age based on the high agency conflict subsample and low agency conflict subsample. Agency conflict is measured by AUR and ADM. Subsamples with AUR higher (ADM lower) than median AUR (ADM) are classified as low agency conflicts, whereas otherwise they will be high agency conflicts. *,**,*** represents the significance at $10 \%, 5 \%$, and $1 \%$ respectively. INST, GOV, PRIV, num, and loan ratio are in decimals.

Table 3. Regression result using Asset Utilization (AUR) as a proxy for agency conflict

\begin{tabular}{|c|c|c|c|c|c|c|}
\hline \multirow{2}{*}{ VARIABLES } & \multicolumn{6}{|c|}{ AUR } \\
\hline & (1) & (2) & (3) & (4) & (5) & (6) \\
\hline INST & $0.493^{* * *}$ & & & $0.457^{* * *}$ & & \\
\hline & $(0.105)$ & & & $(0.106)$ & & \\
\hline GOV & & $\begin{array}{l}0.373^{* *} \\
(0.147)\end{array}$ & & & $\begin{array}{l}0.364^{* *} \\
(0.149)\end{array}$ & \\
\hline PRIV & & & $\begin{array}{c}0.222^{* *} \\
(0.0903)\end{array}$ & & & $\begin{array}{c}0.207^{* *} \\
(0.0916)\end{array}$ \\
\hline NUM & $\begin{array}{l}0.208^{* * *} \\
(0.0376)\end{array}$ & $\begin{array}{l}0.201^{* * *} \\
(0.0377)\end{array}$ & $\begin{array}{l}0.200^{* * *} \\
(0.0377)\end{array}$ & & & \\
\hline LOANRATIO & & & & $\begin{array}{l}0.0846 \\
(0.140)\end{array}$ & $\begin{array}{c}0.145 \\
(0.142)\end{array}$ & $\begin{array}{l}0.0688 \\
(0.141)\end{array}$ \\
\hline SIZE & $\begin{array}{c}-0.0726^{* * *} \\
(0.0167)\end{array}$ & $\begin{array}{c}-0.0834^{* * *} \\
(0.0171)\end{array}$ & $\begin{array}{c}-0.0684^{* * *} \\
(0.0170)\end{array}$ & $\begin{array}{l}-0.0226 \\
(0.0142)\end{array}$ & $\begin{array}{c}-0.0344^{* *} \\
(0.0145)\end{array}$ & $\begin{array}{l}-0.0206 \\
(0.0145)\end{array}$ \\
\hline AGE & $\begin{array}{l}0.300^{* * *} \\
(0.0378)\end{array}$ & $\begin{array}{c}0.282^{* * *} \\
(0.0383)\end{array}$ & $\begin{array}{l}0.304^{* * *} \\
(0.0382)\end{array}$ & $\begin{array}{l}0.305^{* * *} \\
(0.0384)\end{array}$ & $\begin{array}{c}0.289^{* * *} \\
(0.0388)\end{array}$ & $\begin{array}{l}0.307^{* * *} \\
(0.0387)\end{array}$ \\
\hline CONSTANT & $\begin{array}{c}-1.286^{* * *} \\
(0.291)\end{array}$ & $\begin{array}{c}-0.839^{* * *} \\
(0.284)\end{array}$ & $\begin{array}{c}-1.143^{* * *} \\
(0.295)\end{array}$ & $\begin{array}{c}-1.740^{* * *} \\
(0.284)\end{array}$ & $\begin{array}{c}-1.320^{* * *} \\
(0.275)\end{array}$ & $\begin{array}{c}-1.588^{* * * *} \\
(0.287)\end{array}$ \\
\hline Obs. & 1,489 & 1,489 & 1,489 & 1,489 & 1,489 & 1,489 \\
\hline Prob $>\mathrm{Chi}^{2}$ & 0.0000 & 0.0000 & 0.0000 & 0.0000 & 0.0000 & 0.0000 \\
\hline
\end{tabular}

Notes: : ${ }^{*}, * *, * *$ represents a significance level of $10 \%, 5 \%$, and $1 \%$ respectively. AUR, NUM, SIZE and AGE are natural logarithms, while INST, GOV, PRIV and LOANRATIO are in decimals. Higher agency conflict is reflected by low asset utilization ratio. Heteroskedastic-robust standard errors are in parentheses. 
The test result consistently indicated positive and significant (at $\alpha=1 \%$ ) influence of total institutional ownership on the asset utilization ratio. Institutional ownership may improve asset utilization (i.e., indicated by a lower AUR) and hence reduce the agency problem. Government ownership also impacted positively on the asset utilization ratio. The third institutional ownership variable, private institutional ownership also positively affected AUR. Overall, the test result using AUR successfully proved the decrease in agency conflict with the increase of institutional ownership supporting the active surveillance view of Demsetz (1983) in Agrawal and Mandelker (1990), Shleifer and Vishny (1986), Bathala et al. (1994), and Gillan and Starks (2000).

Next, we examined the impact of bank monitoring with two proxies; the number of banks and the loan ratios. First, the regression result on the NUM variable, as the bank monitoring's proxy, consistently showed that the number of banks providing loans had a positive effect on AUR. As the number of banks increased, AUR increased, implying a lower agency conflict. This shows the absence of the free-rider phenomenon in the banks 'monitoring of their debtor firm, which differs from Ang et al. (2000), Ahn and Choi (2009), and Yu et al. (2012). The alternative proxy of bank monitoring, loan ratio shows an insignificant coefficient at any level.

The effect of the firm's size on the agency conflict showed a significant negative coefficient, showing that the larger the firm size, the lower the AUR, which means the agency conflict is increasing. The test result also indicated that the older the firm was, the higher the AUR. This shows that the older firms have less agency conflicts.

\subsection{Agency Conflict as Measured by Sales,} General and Administrative Expenses Ratio

Table 4 summarizes the regression result with the sales, general and administrative (ADM) expenses ratio as the agency conflict proxy. Similar to the previous table, this table contains the regression results for each of the institutional ownerships, with the bank number and bank loan ratio as the bank monitoring's proxy.

The test result proved the effect of total institutional ownership on ADM is negative and significant; implying an increase in total institution ownership will decrease the ADM ratio (the decrease of agency conflict). Government ownership showed no significant impact, whereas private ownership proved to have a significant negative coefficient, suggesting that private institutions will limit the ADM ratio and the agency conflict.

The number of banks (NUM) has significant positive signs (see models1 to3 in Table 4), confirming that as the number of lending banks increases, the agency conflict measured by ADM decreases. This is in line with the results for AUR (Table 3), suggesting there is tougher monitoring and no free-riders among the banks. Furthermore, tests on the influence of the bank loan ratio as the proxy of bank supervision also exhibits a significant negative influence (see models4 to 6 in Table 4). We consistently observed that a lower ADM was linked to a higher bank loan ratio, as stated by Ang et al. (2000), Ahn and Choi (2009), and Setiawan (2012).

For the control variables, we find that the bigger and older firms show less agency conflict. The evidence in Table 3 and Table 4 suggests that creditors/banks will loosen their monitoring of company activities due to their consideration toward the monitoring that is conducted by other 
Table 4. Regression result using Sales, General and Administrative Expenses (ADM) as a proxy for agency conflicts

\begin{tabular}{|c|c|c|c|c|c|c|}
\hline \multirow{2}{*}{ VAR. } & \multicolumn{6}{|c|}{ ADM } \\
\hline & (1) & (2) & (3) & (4) & (5) & (6) \\
\hline INST & $\begin{array}{c}-0.469^{* * *} \\
(0.119)\end{array}$ & & & $\begin{array}{c}-0.442^{* * *} \\
(0.119)\end{array}$ & & \\
\hline GOV & & $\begin{array}{l}0.0294 \\
(0.154)\end{array}$ & & & $\begin{array}{c}-0.0141 \\
(0.155)\end{array}$ & \\
\hline PRIV & & & $\begin{array}{c}-0.336^{* * *} \\
(0.0997)\end{array}$ & & & $\begin{array}{c}-0.303^{* * *} \\
(0.100)\end{array}$ \\
\hline NUM & $\begin{array}{c}-0.116^{* * *} \\
(0.0413)\end{array}$ & $\begin{array}{l}-0.105^{* *} \\
(0.0415)\end{array}$ & $\begin{array}{c}-0.109^{* * *} \\
(0.0413)\end{array}$ & & & \\
\hline LOANRATIO & & & & $\begin{array}{c}-0.477^{* * *} \\
(0.156)\end{array}$ & $\begin{array}{c}-0.485^{* * *} \\
(0.158)\end{array}$ & $\begin{array}{c}-0.440^{* * *} \\
(0.157)\end{array}$ \\
\hline SIZE & $\begin{array}{l}-0.125^{* * *} \\
(0.0183)\end{array}$ & $\begin{array}{c}-0.123^{* * *} \\
(0.0188)\end{array}$ & $\begin{array}{c}-0.133^{* * *} \\
(0.0186)\end{array}$ & $\begin{array}{c}-0.156^{* * *} \\
(0.0157)\end{array}$ & $\begin{array}{c}-0.151^{* * *} \\
(0.0161)\end{array}$ & $\begin{array}{c}-0.162^{* * *} \\
(0.0160)\end{array}$ \\
\hline AGE & $\begin{array}{l}-0.110^{* *} \\
(0.0436)\end{array}$ & $\begin{array}{l}-0.109^{* *} \\
(0.0442)\end{array}$ & $\begin{array}{l}-0.121^{* * *} \\
(0.0438)\end{array}$ & $\begin{array}{l}-0.123^{* * *} \\
(0.0437)\end{array}$ & $\begin{array}{l}-0.121^{* * *} \\
(0.0442)\end{array}$ & $\begin{array}{l}-0.132^{* * *} \\
(0.0439)\end{array}$ \\
\hline CONSTANT & $\begin{array}{c}0.158 \\
(0.315)\end{array}$ & $\begin{array}{l}-0.160 \\
(0.308)\end{array}$ & $\begin{array}{c}0.155 \\
(0.319)\end{array}$ & $\begin{array}{l}0.532^{*} \\
(0.306)\end{array}$ & $\begin{array}{c}0.200 \\
(0.297)\end{array}$ & $\begin{array}{c}0.490 \\
(0.309)\end{array}$ \\
\hline Observations & 1,248 & 1,248 & 1,248 & 1,248 & 1,248 & 1,248 \\
\hline Prob $>$ Chi2 & 0.0000 & 0.0000 & 0.0000 & 0.0000 & 0.0000 & 0.0000 \\
\hline
\end{tabular}

Notes: : *,**** represents a significance level of $10 \%, 5 \%$, and $1 \%$ respectively. ADM, num, size and age are natural logarithms, while INST, GOV, PRIV and loan ratio are in decimals. Higher ADM indicates higher agency conflicts. Heteroskedastic-robust standard errors are in parentheses.

banks, which in the end will result in a lack of monitoring of the company, which is reflected in its agency conflict. This study did not find evidence of the free-rider phenomenon among lending banks. Weak protection for creditors in developing countries, such as Indonesia, allegedly explains this condition. The banks continue to carry out their optimal supervision, despite other banks already monitoring the company.

\subsection{The Effect of Institutional Ownership on Agency Conflicts at Different Bank Monitoring Levels}

a. Total Institutional Ownership

In the previous section, we discussed the results of the regression on the individual impact of the main variables (INST) on AUR and ADM. In this section, we examine these impacts while considering different proxies of bank monitoring. In other word, we question whether the effect of INST will vary at high or low numbers of banks (dNUM) and at high or low bank loan ratios (dLOANRATIO).

Table 5 reports the regression results to test the impacts of total institutional ownership at different bank numbers and debt ratio levels. Agency conflict measured byAUR reveals the interaction variables of INST*dNUM and INST*dLOANRATIO have significant negative coefficients. These indicate a weakening positive influence of the total institutional ownership variable on AUR at higher bank numbers and bank debt ratios. Hence, the effect of INST becomes less positive when there are high numbers of banks that monitor a firm. But when the agency conflict is measured with the ADM ratio, two interaction variables show insignificant coefficients. We proceed to distinguish the type of institutional ownership in the following section. 
Table 5. Total institutional ownership effect at different levels of bank monitoring

\begin{tabular}{lcccccccc}
\hline \multirow{2}{*}{ VARIABLE } & \multicolumn{9}{c}{ AUR } & \multicolumn{5}{c}{ ADM } \\
\cline { 2 - 9 } & $(1)$ & $(2)$ & $(3)$ & $(4)$ & $(5)$ & $(6)$ & $(7)$ & $(8)$ \\
\hline INST & $0.472^{* * *}$ & $0.875^{* * *}$ & $0.472^{* * *}$ & $0.657^{* * *}$ & $-0.476^{* * *}$ & $-0.515^{* * *}$ & $-0.480^{* * *}$ & $-0.665^{* * *}$ \\
& $(0.105)$ & $(0.158)$ & $(0.105)$ & $(0.150)$ & $(0.118)$ & $(0.180)$ & $(0.118)$ & $(0.170)$ \\
dNUM & $0.0880^{*}$ & $0.571^{* * *}$ & & & 0.0115 & -0.0356 & & \\
& $(0.0497)$ & $(0.151)$ & & & $(0.0540)$ & $(0.171)$ & & \\
INST*dNUM & & $-0.709^{* * *}$ & & & & 0.0683 & & \\
dLOANRATIO & & $(0.208)$ & & & & $(0.235)$ & & \\
& & & 0.0216 & $0.263^{*}$ & & & $-0.148^{* * *}$ & $-0.388^{* *}$ \\
INST*dLOANRATIO & & & $(0.0452)$ & $(0.146)$ & & & $(0.0489)$ & $(0.166)$ \\
& & & & $-0.357^{*}$ & & & & 0.352 \\
SIZE & $-0.0312^{* *}$ & $-0.0347^{* * *}$ & -0.0212 & -0.0221 & $-0.156^{* * *}$ & $-0.156^{* * *}$ & $-0.157^{* * *}$ & $-0.156^{* * *}$ \\
& $(0.0151)$ & $(0.0150)$ & $(0.0140)$ & $(0.0140)$ & $(0.0166)$ & $(0.0167)$ & $(0.0153)$ & $(0.0153)$ \\
AGE & $0.300^{* * * *}$ & $0.297^{* * *}$ & $0.301^{* * *}$ & $0.301^{* * *}$ & $-0.111^{* *}$ & $-0.110^{* *}$ & $-0.126^{* * *}$ & $-0.129^{* * *}$ \\
& $(0.0381)$ & $(0.0380)$ & $(0.0385)$ & $(0.0385)$ & $(0.0436)$ & $(0.0436)$ & $(0.0437)$ & $(0.0437)$ \\
CONSTANT & $-1.673^{* * *}$ & $-1.872^{* * *}$ & $-1.770^{* * *}$ & $-1.868^{* * *}$ & 0.453 & 0.472 & $0.552^{*}$ & $0.650^{* *}$ \\
& $(0.284)$ & $(0.289)$ & $(0.281)$ & $(0.286)$ & $(0.306)$ & $(0.313)$ & $(0.302)$ & $(0.308)$ \\
& & & & & & & & \\
Observations & 1,489 & 1,489 & 1,489 & 1,489 & 1,277 & 1,277 & 1,277 & 1,277 \\
Number of firm & 304 & 304 & 304 & 304 & 285 & 285 & 285 & 285 \\
Prob>Chi ${ }^{2}$ & 0.0000 & 0.0000 & & 0.0000 & 0.0000 & 0.0000 & 0.0000 & 0.0000 \\
Joint effect & & 0.166 & & $0.300^{* *}$ & & $-0.4467^{* * *}$ & & $-0.313^{*}$ \\
Prob>chi ${ }^{2}$ & & 0.2292 & & 0.0379 & & 0.0039 & & 0.0515 \\
\hline
\end{tabular}

Notes: dNUM equals to 1 for firms with higher-than-median bank numbers and 0 otherwise. dLOANRATIO has the value of 1 if the number of banks is higher than its median number and 0 otherwise. *,**,*** represents significance level of $10 \%, 5 \%$, and $1 \%$ respectively. AUR, ADM, size and age are natural logarithms, dnum and dLOANRATIO are dummies, while INST is in decimals. Heteroskedastic-robust standard errors are in parentheses.

Table 6. Government ownership effect at different levels of bank monitoring

\begin{tabular}{|c|c|c|c|c|c|c|c|c|}
\hline \multirow{2}{*}{ VARIABLE } & \multicolumn{4}{|c|}{ AUR } & \multicolumn{4}{|c|}{ ADM } \\
\hline & (1) & (2) & (3) & (4) & $(5)$ & (6) & (7) & $(8)$ \\
\hline GOV & $\begin{array}{l}0.351^{* *} \\
(0.148)\end{array}$ & $\begin{array}{l}0.0540 \\
(0.300)\end{array}$ & $\begin{array}{l}0.366^{* *} \\
(0.150)\end{array}$ & $\begin{array}{l}0.349^{* *} \\
(0.165)\end{array}$ & $\begin{array}{l}0.0478 \\
(0.154)\end{array}$ & $\begin{array}{l}0.556^{*} \\
(0.299)\end{array}$ & $\begin{array}{c}-0.0144 \\
(0.155)\end{array}$ & $\begin{array}{l}-0.0435 \\
(0.172)\end{array}$ \\
\hline Dnum & $\begin{array}{c}0.0892^{*} \\
(0.0500)\end{array}$ & $\begin{array}{c}0.0782 \\
(0.0509)\end{array}$ & & & $\begin{array}{c}0.0123 \\
(0.0543)\end{array}$ & $\begin{array}{c}0.0354 \\
(0.0555)\end{array}$ & & \\
\hline GOV*dNUM & & $\begin{array}{c}0.386 \\
(0.339)\end{array}$ & & & & $\begin{array}{l}-0.679^{* *} \\
(0.343)\end{array}$ & & \\
\hline dLOANRATIO & & & $\begin{array}{c}0.0383 \\
(0.0459)\end{array}$ & $\begin{array}{c}0.0359 \\
(0.0468)\end{array}$ & & & $\begin{array}{l}-0.146^{* * *} \\
(0.0497)\end{array}$ & $\begin{array}{c}-0.150^{* * *} \\
(0.0510)\end{array}$ \\
\hline GOV*dLOANRATIO & & & & $\begin{array}{l}0.0876 \\
(0.347)\end{array}$ & & & & $\begin{array}{c}0.137 \\
(0.348)\end{array}$ \\
\hline SIZE & $\begin{array}{c}-0.0431^{* * *} \\
(0.0154)\end{array}$ & $\begin{array}{c}-0.0430^{* * *} \\
(0.0154)\end{array}$ & $\begin{array}{c}-0.0333^{* *} \\
(0.0143)\end{array}$ & $\begin{array}{c}-0.0334^{* *} \\
(0.0143)\end{array}$ & $\begin{array}{l}-0.153^{* * *} \\
(0.0171)\end{array}$ & $\begin{array}{l}-0.153^{* * *} \\
(0.0171)\end{array}$ & $\begin{array}{l}-0.152^{* * *} \\
(0.0157)\end{array}$ & $\begin{array}{l}-0.152^{* * * *} \\
(0.0157)\end{array}$ \\
\hline AGE & $\begin{array}{l}0.283^{* * *} \\
(0.0385)\end{array}$ & $\begin{array}{l}0.279^{* * *} \\
(0.0387)\end{array}$ & $\begin{array}{l}0.285^{* * *} \\
(0.0389)\end{array}$ & $\begin{array}{l}0.284^{* * *} \\
(0.0389)\end{array}$ & $\begin{array}{l}-0.109^{* *} \\
(0.0441)\end{array}$ & $\begin{array}{l}-0.100^{* *} \\
(0.0443)\end{array}$ & $\begin{array}{l}-0.122^{* * *} \\
(0.0442)\end{array}$ & $\begin{array}{l}-0.123^{* * *} \\
(0.0442)\end{array}$ \\
\hline CONSTANT & $\begin{array}{c}-1.229^{* * * *} \\
(0.275)\end{array}$ & $\begin{array}{l}-1.216^{* * *} \\
(0.275)\end{array}$ & $\begin{array}{c}-1.332^{* * *} \\
(0.271)\end{array}$ & $\begin{array}{c}-1.329^{* * *} \\
(0.271)\end{array}$ & $\begin{array}{c}0.103 \\
(0.297)\end{array}$ & $\begin{array}{l}0.0801 \\
(0.296)\end{array}$ & $\begin{array}{c}0.182 \\
(0.292)\end{array}$ & $\begin{array}{c}0.190 \\
(0.292)\end{array}$ \\
\hline
\end{tabular}




\begin{tabular}{lcccccccc}
\hline Observations & 1,489 & 1,489 & 1,489 & 1,489 & 1,277 & 1,277 & 1,277 & 1,277 \\
Number of firm & 304 & 304 & 304 & 304 & 285 & 285 & 285 & 285 \\
Prob $>$ Chi $^{2}$ & 0.0000 & 0.0000 & 0.0000 & 0.0000 & 0.0000 & 0.0000 & 0.0000 & 0.0000 \\
Joint effect & & $0.440^{* * *}$ & & 0.4366 & & -0.123 & 0.0935 \\
Prob>chi' & & 0.0086 & & 0.1659 & & 0.4859 & 0.7661 \\
\hline
\end{tabular}

Notes: Dnumequals 1 for firms with higher-than-median bank numbers and 0 otherwise. dLOANRATIO has a value of 1 if the number of banks is higher than its median number and 0 otherwise. *,**,*** represents the significance at $10 \%$, $5 \%$, and $1 \%$ respectively. AUR, ADM, size and age are natural logarithms; dNUM and dLOANRATIO are dummies, while GOV is in decimals. Heteroskedastic-robust standard errors are in parentheses.

Table 7. Private institutional ownership effect at different levels of bank monitoring

\begin{tabular}{|c|c|c|c|c|c|c|c|c|}
\hline \multirow{2}{*}{ VARIABLE } & \multicolumn{4}{|c|}{ AUR } & \multicolumn{4}{|c|}{ ADM } \\
\hline & (1) & (2) & (3) & (4) & (5) & (6) & (7) & (8) \\
\hline PRIV & $\begin{array}{l}0.222^{* *} \\
(0.0907)\end{array}$ & $\begin{array}{l}0.705^{* * *} \\
(0.144)\end{array}$ & $\begin{array}{l}0.220^{* *} \\
(0.0912)\end{array}$ & $\begin{array}{l}0.248^{* *} \\
(0.118)\end{array}$ & $\begin{array}{l}-0.353^{* * *} \\
(0.0992)\end{array}$ & $\begin{array}{c}-0.576^{* * *} \\
(0.159)\end{array}$ & $\begin{array}{l}-0.331^{* * *} \\
(0.0992)\end{array}$ & $\begin{array}{c}-0.360^{* * *} \\
(0.128)\end{array}$ \\
\hline dNUM & $\begin{array}{l}0.0881^{*} \\
(0.0500)\end{array}$ & $\begin{array}{l}0.590^{* * *} \\
(0.127)\end{array}$ & & & $\begin{array}{c}0.0118 \\
(0.0541)\end{array}$ & $\begin{array}{l}-0.216 \\
(0.138)\end{array}$ & & \\
\hline PRIV*dNUM & & $\begin{array}{l}-0.769^{* * *} \\
(0.178)\end{array}$ & & & & $\begin{array}{l}0.348^{*} \\
(0.194)\end{array}$ & & \\
\hline dLOANRATIO & & & $\begin{array}{c}0.0129 \\
(0.0456)\end{array}$ & $\begin{array}{l}0.0541 \\
(0.119)\end{array}$ & & & $\begin{array}{l}-0.132^{* * *} \\
(0.0492)\end{array}$ & $\begin{array}{l}-0.175 \\
(0.129)\end{array}$ \\
\hline $\begin{array}{l}\text { PRIV* } \\
\text { dLOANRATIO }\end{array}$ & & & & $\begin{array}{c}-0.0644 \\
(0.173)\end{array}$ & & & & $\begin{array}{l}0.0667 \\
(0.187)\end{array}$ \\
\hline SIZE & $\begin{array}{l}-0.0289^{*} \\
(0.0154)\end{array}$ & $\begin{array}{l}-0.0344^{* *} \\
(0.0153)\end{array}$ & $\begin{array}{l}-0.0190 \\
(0.0143)\end{array}$ & $\begin{array}{l}-0.0189 \\
(0.0143)\end{array}$ & $\begin{array}{l}-0.164^{* * *} \\
(0.0170)\end{array}$ & $\begin{array}{l}-0.161^{* * *} \\
(0.0170)\end{array}$ & $\begin{array}{l}-0.163^{* * *} \\
(0.0156)\end{array}$ & $\begin{array}{l}-0.163^{* * *} \\
(0.0156)\end{array}$ \\
\hline AGE & $\begin{array}{l}0.303^{* * *} \\
(0.0385)\end{array}$ & $\begin{array}{l}0.289^{* * *} \\
(0.0384)\end{array}$ & $\begin{array}{l}0.303^{* * *} \\
(0.0388)\end{array}$ & $\begin{array}{l}0.303^{* * *} \\
(0.0388)\end{array}$ & $\begin{array}{l}-0.122^{* * *} \\
(0.0438)\end{array}$ & $\begin{array}{l}-0.114^{* * *} \\
(0.0439)\end{array}$ & $\begin{array}{l}-0.134^{* * *} \\
(0.0439)\end{array}$ & $\begin{array}{l}-0.135^{* * *} \\
(0.0439)\end{array}$ \\
\hline CONSTANT & $\begin{array}{c}-1.521^{* * *} \\
(0.287)\end{array}$ & $\begin{array}{c}-1.728^{* * *} \\
(0.290)\end{array}$ & $\begin{array}{c}-1.612^{* * *} \\
(0.284)\end{array}$ & $\begin{array}{l}-1.626^{* * *} \\
(0.286)\end{array}$ & $\begin{array}{c}0.441 \\
(0.309)\end{array}$ & $\begin{array}{l}0.533^{*} \\
(0.313)\end{array}$ & $\begin{array}{l}0.504^{*} \\
(0.304)\end{array}$ & $\begin{array}{l}0.517^{*} \\
(0.306)\end{array}$ \\
\hline Observations & 1,489 & 1,489 & 1,489 & 1,489 & 1,277 & 1,277 & 1,277 & 1,277 \\
\hline Number of firm & 304 & 304 & 304 & 304 & 285 & 285 & 285 & 285 \\
\hline Prob $>\mathrm{Chi}^{2}$ & 0.0000 & 0.0000 & 0.0000 & 0.0000 & 0.0000 & 0.0000 & 0.0000 & 0.0000 \\
\hline Joint effect & & -0.064 & & 0.1836 & & $-0.228^{*}$ & & $-0.2933^{* *}$ \\
\hline Prob $>$ chi $^{2}$ & & 0.5706 & & 0.1716 & & 0.0604 & & 0.0441 \\
\hline
\end{tabular}

Notes: dNUM equals 1 for firms with higher-than-median bank numbers and 0 otherwise. dLOANRATIO has a value of 1 if the number of banks is higher than its median number and 0 otherwise. $*, * *, * *$ represents the significance at $10 \%$, $5 \%$, and $1 \%$ respectively. AUR, ADM, size and age are natural logarithms, dnum and dloan ratio are dummies, while $\mathrm{GOV}$ is in decimals. Heteroskedastic-robust standard errors are in parentheses.

\section{b. Government Institutional Ownership}

Table 6 shows the influence of government institutional ownership on agency conflict at different bank supervision levels. The test result displays that there was no significant interaction variable. Change only occurred in the government institutional ownership variable, which went from a significant positive influence on
AUR to insignificant at high bank number levels.

The use of the ADM ratio is as an agency conflict proxy at different levels of bank monitoring. The test result showed only the GOV*dNUM interaction variable had significant coefficient, indicating that higher government ownership will increase the ADM 
ratio, but at a high bank number level this influence will be weakened.

\section{c. Private Institutional Ownership}

Table 7 exhibits the differences in the impact of private institutional ownership on agency conflict at different bank monitoring levels. The results, particularly in model 2, showed the PRIV*dNUM interaction variable had a significant negative coefficient. The interpretation is the positive impact of private institutional ownership on AUR tends to weaken at a higher bank number level, but is not significant at the higher bank loan ratio level (model 4).

In models4 to 6, we found that PRIV*dNUM had significant coefficients on ADM, indicating that private institutional ownership can effectively limit the sales, general and administrative (ADM) expenses but it weakens at a higher number of banks.

Overall, these results suggest that the influence of institutional ownership on agency conflict varies with different levels of bank monitoring, supporting our arguments above. The incentive of shareholders to monitor the firm apparently weakens as they consider that there are other parties (i.e. banks) that also keep an eye on firms, particularly related to their use of assets and other expenses. Institutional investors tend to loosen their monitoring when firms are at high bank monitoring levels, implying free-riding problems.

\section{CONCLUSION, LIMITATIONS AND SUGGESTIONS}

\section{Conclusion}

Using data from non-financial firms listed on the Indonesian Stock Exchange, this study analyzes the effect of institutional ownership and bank monitoring on agency conflicts. Total institutional ownership, government ownership, and private ownership mitigate agency conflicts measured by the AUR ratio, showing that firms with higher institutional ownership have a better AUR ratio. Institutional shareholders use their privilege to be able to supervise the firms better (Shleifer \&Vishny, 1986; Demsetz, 1983in Agrawal \&Mandelker, 1990; Bathala et al., 1994; Ang et al., 2000; Gillan\& Starks, 2000; Noe, 2002; Delis et al, 2017).

With regard to the ADM ratio, government ownership does not have a significant influence. One of the possible explanations for this is the government lacks the skills to monitor firms, compared to private institutions (Shleifer \&Vishny, 1994 in La Porta, 1999; Qi et al., 2000). Singh and Davidson (2003) argued that the ADM ratio tends to be invisible when compared to sales-related cash flow (AUR) so investors pay less concern to it.

The number of bank lenders has a negative influence on agency conflict, measured by the AUR and ADM ratios. Firms borrowing from more banks have higher AUR and lower ADM, showing less agency conflict. No free-rider phenomenon in bank influence is found in this study. Note that the investor protection in developing countries tends to be weak, so that the bank lenders still have incentives to exercise supervision despite the other bank lenders ( $\mathrm{Yu}$ et al., 2012).

Meanwhile, the bank loan ratio is found to affect the agency conflict proxied with the ADM ratio, and is significantly negative. There is an increase in the banks' incentive to supervise the firms with high bank debt ratios, as argued by Ang et al. (2000), Khalil and Parigi (1998) in Dass and Massa (2011), Ahn and Choi (2009), and Fok et al. (2004). The presence of the freerider problem is indicated by the weakening influence of institution ownership at high bank monitoring levels(bank number and bank debt ratio). The shareholders consider the monitoring 
by the banks is sufficient so they relax their supervision.

\section{Limitations and Suggestions}

The institutional ownerships in this study are only measured by direct ownership, based on the available company reports. Further research may consider indirect ownership's measurement or the ultimate owner to reflect the firms' ownership better. The type of institutional ownership might be divided into more groups to assess the research results and their persistence. In addition, the proxy of the agency conflict in this research was limited to accounting items. The use of market-related measurements, such as Tobins' Q, is strongly suggested for any future studies.

\section{REFERENCES}

Agrawal, A., \& Mandelker, G. N. (1990). Large shareholders and the monitoring of managers: The case of antitakeover charter amendments. Journal of Financial and Quantitative analysis, 143-161. doi:10.2307/2330821.

Ahmad, R., \&Aliahmed, H.J., \& Ab-Razak, N.H., (2008). Government ownership and performance: An analysis of listed companies in Malaysia. Working paper. Available at:

https://ssrn.com/abstract=1252072

or http://dx.doi.org/10.2139/ssrn.1252072.

Ahn, S., \& Choi, W. (2009). The role of bank monitoring in corporate governance: Evidence from borrowers' earnings management behavior. Journal of banking \& finance, 33(2), 425-434. https://doi.org/10.1016/j.jbankfin.2008.08.0 13.

Ang, J.S., \& Ding, D.K. (2006). Government ownership and the performance of government-linked companies: The case of Singapore. Journal of Multinational Financial Management, 16(1): 64-88. https://doi.org/10.1016/j.mulfin.2005.04.010.
Ang, J. S., Cole, R. A., \& Lin, J. W. (2000). Agency costs and ownership structure. the Journal of Finance, 55(1), 81-106. https://doi.org/10.1111/0022-1082.00201.

Bathala, C. T., Moon, K. P., \& Rao, R. P. (1994). Managerial ownership, debt policy, and the impact of institutional holdings: An agency perspective. Financial management, 38-50.doi: 10.2307/3665620.

Beck, T., Demirgüç-Kunt, A., \& Levine, R. (2010). Financial institutions and markets across countries and over time: The updated financial development and structure database. The World Bank Economic Review, 24(1), 77-92.Available at www.jstor.org/stable/40647421

Boot, Arnoud W. A. (2000). Relationship banking: What do we know? Journal of Financial Intermediation 9 (1): 7-25. https://doi.org/10.1006/jfin.2000.0282.

Byers, S. S., Fields, L. P., \& Fraser, D. R. (2008). Are corporate governance and bank monitoring substitutes: Evidence from the perceived value of bank loans. Journal of Corporate Finance, 14(4), 475-483.DOI: 10.1016/j.jcorpfin.2008.06.002.

Chen, J. (2001). Ownership structure as corporate governance mechanism: Evidence from Chinese listed companies. Economics of Planning, 34(1-2), 53-72.doi: https://doi.org/10.1023/A:1017548432111.

Chen, X., Harford, J., \& Li, K. (2007). Monitoring: Which institutions matter?. Journal of financial Economics, 86(2), 279305.https://doi.org/10.1016/j.jfineco.2006.0 9.005 .

Claessens, S., Djankov, S., \&Lang, L.H.P. (2000), The separation of ownership and control in East Asian corporation.Journal of Financial Economics, 58 (1/2): 81112.https://doi.org/10.1016/S0304405X(00)00067-2

Claessens, S., Djankov, S., Fan, J.P.H., \&Lang, L. (2002), Disentangling the incentive and entrenchment effects of large sharehold- 
ings.Journal of Finance, Vol. 57(6):. 27412771. www.jstor.org/stable/3094542

Claessens, S., \&Yurtoglu, B. (2013), Corporate governance in emerging markets: A survey.Emerging Markets Review, Vol. 15:1-33.

https://doi.org/10.1016/j.ememar.2012.03.0 02.

Chung, K.,\& Lee, C. (2020). Voting methods for director election, monitoring costs, and institutional ownership. Journal of Banking \& Finance. 113. 105738. 10.1016/ j.jbankfin.2020.105738.

Dass, N., \& Massa, M. (2011). The impact of a strong bank-firm relationship on the borrowing firm. The Review of Financial Studies, 24(4), 1204-1260. doi $10.2307 / 20869268$.

David, P., \& Kochhar, R. (1996). Barriers to effective corporate governance by institutional investors: Implications for theory and practice. European Management Journal, 14(5), 457466.https://doi.org/10.1016/02632373(96)00039-4.

Diamond, D.W. (1984). Financial intermediation and delegated monitoring. Review of Economic Studies, 15(3): 393-414. $10.2307 / 2297430$.

Demirgüç-Kunt, A.,\& Levine, R.E. (1999). Bank-based and market-based financial systems: Cross-country comparisons. World Bank Policy Working Paper No. 2143. Available at SSRN:

https://ssrn.com/abstract=569255

Delis, M. D., Kokas, S., \& Ongena, S. (2017). Bank market power and firm performance. Review of Finance, 21(1), 299-326. https://doi.org/10.1093/rof/rfw004

Demsetz, H. (1983). The Structure of Ownership and the Theory of the Firm. The Journal of Law \& Economics, 26(2), 375-390. Available from www.jstor.org/stable/725108

Fama, E. F. (1985). What's different about banks?. Journal of monetary economics,
15(1), 29-39.https://doi.org/10.1016/03043932(85)90051-0.

Ferreira, M. A., \& Matos, P. (2008). The colors of investors' money: The role of institutional investors around the world. Journal of financial economics, 88(3), 499-533. https://doi.org/10.1016/j.jfineco.2007.07.00 3.

Fleming, G., Heaney, R., \& McCosker, R. (2005). Agency costs and ownership structure in Australia. Pacific-Basin Finance Journal, 13(1), 29-52.

https://doi.org/10.1016/j.pacfin.2004.04.001

Florackis, C. (2008). Agency costs and corporate governance mechanisms: evidence for UK firms. International Journal of Managerial Finance. doi: 10.1108/17439130810837375.

Fok, R. C., Chang, Y. C., \& Lee, W. T. (2004). Bank relationships and their effects on firm performance around the Asian financial crisis: Evidence from Taiwan. Financial Management, 89-112.

www.jstor.org/stable/3666160.

Freixas, X.,\&Rochet,J., (2008) Microeconomics of Banking, $2^{\text {nd }}$ Edition, The MIT Press, https://EconPapers.repec.org/RePEc:mtp:titl es:0262062704.

Gillan, S.L., \&Starks, L.T., (2000). Corporate governance proposals and shareholder activism: the role of institutional investors. Journal of Financial Economics, 57, 275305.https://doi.org/10.1016/S0304405X(00)00058-1.

Jensen, M. C. (1986). Agency costs of free cash flow, corporate finance, and takeovers. The American economic review, 76(2), 323-329. www.jstor.org/stable/1818789.

Jensen, M.C., \&Meckling, H.W. (1976). Theory of the firm: Managerial behavior, agency costs and ownership structure. Journal of Financial Economics, 3(4), 305360.https://doi.org/10.1016/0304405X(76)90026-X.

La Porta, R., Lopez-de-Silanes, F., Shleifer, A., \& Vishny, R. (1999). Corporate governance around the world. Journal of Finance, 
54(2), 471-517.

https://doi.org/10.1111/0022-1082.00115.

Lin, Y. R., \& Fu, X. M. (2017). Does institutional ownership influence firm performance? Evidence from China. International Review of Economics \& Finance, 49, 17-57.

https://doi.org/10.1016/j.iref.2017.01.021.

Lin, F. L., \& Lin, H. L. (2013). Ultimate controller ownership and firm value in Taiwan. Emerging Markets Finance and Trade, 49(1), 68-81.

https://doi.org/10.2753/REE1540496X490104

McKnight, P. J., \& Weir, C. (2009). Agency costs, corporate governance mechanisms and ownership structure in large UK publicly quoted companies: A panel data analysis. The quarterly review of economics and finance, 49(2), 139-158.

https://doi.org/10.1016/j.qref.2007.09.008.

Muniandy, P., Tanewski, G., \& Johl, S. K. (2016). Institutional investors in Australia: Do they play a homogenous monitoring role?. Pacific-Basin Finance Journal, 40, 266-288.

https://doi.org/10.1016/j.pacfin.2016.01.001

Noe, T. H. (2002). Investor activism and financial market structure. The Review of Financial Studies, 15(1), 289-318.Retrieved from www.jstor.org/stable/2696805.

Otoritas Jasa Keuangan (OJK). (2017). Capital Market Statistics December- 42017. accessed January, 112018.

https://www.ojk.go.id/id/kanal/pasar-

modal/data-dan-statistik/statistik-pasar-

modal/Default.aspx.

Otoritas Jasa Keuangan (OJK). (2016). Indonesia Banking Statistics December2016. accessed January, 202018. https://www.ojk.go.id/id/kanal/perbankan/d ata-dan-statistik/statistik-perbankanindonesia/Default.aspx.

Qi, D., Wu, W., \& Zhang, H. (2000). Shareholding structure and corporate performance of partially privatized firms: Evidence from listed Chinese companies. Pacific-Basin

Finance Journal, 8(5), 587-610. https://doi.org/10.1016/S0927538X(00)00013-5.

Setiawan, R. (2012). Bank Monitoring, Kebijakan Perusahaan, dan Kinerja Perusahaan. Universitas Gadjah Mada: Disertasi.

Setiyono, B., \& Tarazi, A. (2014). Disclosure, ownership structure and bank risk: Evidence from Asia. In 27th Australasian finance and banking conference. Available at SSRN: https://ssrn.com/abstract $=2395315$ or http://dx.doi.org/10.2139/ssrn.23953152014

Shepherd, J., Tung, F., \& Yoon, A. (2007). Cross-monitoring and corporate governance. Available at SSRN 914229. http://dx.doi.org/10.2139/ssrn.914229

Shleifer, A., \& Vishny, R. W. (1997). A Study of Corporate Governance. The Journal of Finance, LII, 2.

https://doi.org/10.1111/j.1540-

6261.1997.tb04820.x.

Shleifer, A., \& Vishny, R. W. (1986). Large shareholders and corporate control. Journal of political economy, 94(3, Part 1), 461-488. https://www.jstor.org/stable/1833044.

Singh, M., \& Davidson III, W. N. (2003). Agency costs, ownership structure and corporate governance mechanisms. Journal of Banking \& Finance, 27(5), 793-816. https://doi.org/10.1016/S03784266(01)00260-6.

Wiwattanakantang, Yupana. "Controlling shareholders and corporate value: Evidence from Thailand." Pacific-Basin Finance Journal 9, no. 4 (2001): 323-362. https://doi.org/10.1016/S0927538X(01)00022-1.

Yu, H. C., Sopranzetti, B. J., \& Lee, C. F. (2012). Multiple banking relationships, managerial ownership concentration and firm value: A simultaneous equations approach. The Quarterly Review of Economics and Finance, 52(3), 286-297. https://doi.org/10.1016/j.qref.2012.07.002. 